УДК 347.921 (477)

DOI https://doi.org/10.51989/NUL.2021.5.3

\title{
СТРАТЕГІЯ І ТАКТИКА ЗАТЯГУВАННЯ ЦИВІЛЬНОГО ПРОЦЕСУ ТА СПОСОБИ ПРОТИДІї
}

\section{Тріпульський Григорій Яковлевич,}

кандидат юридичних наук, доцент кафедри цивільного процесу

Національного університету «Одеська юридична академія», керуючий партнер

ТОВ «ЮКК "ДЕ-ЮРЕ"»

\section{Іліопол Інна Михайлівна,}

кандидат юридичних наук, доцент кафедри цивільного процесу

Національного університету «Одеська юридична академія»

Затягування цивільного процесу та зловживання цивільними процесуальними правами є одними з найобговорюваних питань у науковому просторі цивільного процесуального права України. Багато років поспіль у судовій практиці існувала проблема порушення розумних строків розгляду справи, зокрема із причин затягування цивільного процесу. Велика кількість звернень громадян до Європейського суду з прав людини проти України спричинила необхідність вирішення цієї проблеми та вдосконалення законодавства, запровадження нових інститутів і принципів та розроблення способів протидії затягуванню цивільного процесу.

Затягування судового процесу як термін не має законодавчого закріплення, однак було предметом дослідження на практичному і теоретичному рівнях, особливо адвокатами та суддями, адже вони часто стикаються з такою проблемою.

Затягування цивільного процесу є одним з інструментів використання цивільних процесуальних прав із метою зловживання процесуальними правами. Але варто розмежовувати ці два поняття, виходячи з їхніх характерних ознак.

Отже, метою написання статті $\epsilon$ окреслення наявних способів затягування цивільного процесу та способів зловживання цивільними процесуальними правами з метою затягування цивільного процесу як основних видів процесуальних правопорушень, а також формування способів протидії цим негативним явищам цивільного судочинства. Окреслено механізми припинення затягування цивільного процесу та запобігання такому.

Систематизація способів затягування цивільного процесу має теоретичне та практичне значення, адже сформовані висновки щодо способів протидії затягуванню цивільного процесу направлені на вдосконалення механізмів запобігання цивільним процесуальним правопорушенням, що сприяє ефективності здійснення цивільного судочинства.

Ключові слова: цивільний процес, затягування цивільного процесу, запобігання затягуванню цивільного процесу, зловживання процесуальними правами, способи протидії.

\section{Tripulskyi Hryhorii, Iliopol Inna. Strategy and tactics of undue delay in civil proceeding and methods of counteraction}

Delaying civil procedure and abuse of civil procedural rights are among the most discussed issues in the scientific space of civil procedural law of Ukraine. For many years in judicial practice, there was a problem of violation of reasonable terms for the consideration of the case, including for reasons of delaying the civil process. A large number of citizens' appeals to the European Court of Human Rights against Ukraine made it necessary to solve this problem and improve legislation, introducing new institutions and principles and developing ways to counteract the protraction of the civil process.

Delaying the trial, as a definition, does not have a legislative basis, however, it was the subject of research, both on a practical and theoretical level, especially by lawyers and judges, because they often face such a problem. 
Dragging out the civil process, in full measure, is one of the tools for using civil procedural rights in order to abuse procedural rights. However, one should distinguish between these two concepts based on their distinctive features.

Therefore, the purpose of writing the article is to determine the existing ways of delaying the civil procedure and methods of abuse of civil procedural rights in order to delay the civil procedure, as the main types of procedural offenses, as well as the formation of ways to counteract these negative disadvantages of civil proceedings. The mechanisms of termination and prevention of delaying the civil process have been determined.

Thus, the systematization of the methods of delaying the civil procedure has theoretical and practical significance, because the conclusions formed regarding the methods of counteracting the delay in the civil procedure are aimed at improving the mechanisms for preventing civil procedural offenses, contributing to the effectiveness of the implementation of civil proceedings.

Key words: civil procedure, undue delay of civil procedure, prevention of undue delay of civil procedure, abuse of procedural rights, ways to counter.

\section{Постановка проблеми. Протягом} багатьох років у судовій практиці існувала проблема порушення розумних строків розгляду справи, зокрема із причин затягування цивільного процесу. Багато звернень до Європейського суду з прав людини (далі - ЄСПЛ) проти України стосувались саме цього питання, адже отримання рішення суду через декілька років, а іноді навіть через декілька десятків років може стати неактуальним, порушує права на судовий захист та не відповідає завданням цивільного судочинства. Так, у справі «Дяченко та інші проти України» від 6 липня 2017 р. ЄСПЛ об'єднав дев'ять заяв та оголосив скарги щодо надмірної тривалості цивільних проваджень та відсутності в національному законодавстві ефективного засобу юридичного захисту прийнятними та такими, що свідчать про порушення п. 1 ст. 6 та ст. 13 Конвенції про захист прав людини і основоположних свобод. Європейський суд з прав людини вкотре зазначив, що розумність тривалості судового розгляду повинна оцінюватися у світлі обставин справи та з урахуванням таких критеріїв, як складність справи, поведінка заявників та відповідних органів влади, а також важливість предмета спору для заявників (див. рішення у справах «Світлана Науменко проти України», «Єфименко проти України», «Фрідлендер проти Франції») [1].

Реформування процесуального законодавства, зокрема закріплення серед основних засад цивільного судочинства принципу неприпустимості зловживання процесуальними правами, збільшення розумних строків розгляду справи та запровадження спрощеного позовного провадження, загалом покращило становище, однак і натепер ця тема залишається актуальною.

Стан дослідження теми. Затягування цивільного процесу як один зі способів зловживання процесуальними правами в різні періоди було предметом дослідження таких учених, як: М.М. Агарков, Є.В. Васьковський, Н.Ю. Голубєва, Я.В. Грель, О.В. Дзера, О.М. Єрмакова, I.В. Жилінкова, В.В. Комаров, Т.А. Кудря, О.М. Кузнець, Д.Д. Луспеник, В.В. Луць, Н.О. Чечіна, П.С. Елькінд, А.В. Юдін та інші. Значну увагу питанню затягування цивільного процесу було приділено в дисертаційному дослідженні Г.І. Марунич.

Метою написання статті $\epsilon$ системне дослідження форм та способів затягування цивільного процесу; виявлення відмінностей затягування цивільного процесу від зловживання цивільними процесуальними правами, а також розроблення пропозицій щодо засобів запобігання затягуванню цивільного процесу.

\section{Виклад основного матеріалу дослі- дження 3 повним обґрунтуванням отриманих наукових результатів.} У судовій практиці, на жаль, $є$ такі негласні правила серед суб'єктів правовідносин якщо не можна «виграти» справу, треба хоча 6 відстрочити ухвалення судового рішення та його виконання. Це може бути вигідно як відповідачу (наприклад, щоб реалізувати спірне майно, «втратити» докази тощо), так і позивачу (наприклад, щоб змусити іншу сторону домовлятися; подання завідомо безпідставного позову тощо). Існує декілька цілком законних способів затягування процесу: 1) подання заяв та клопотань (п. 3 ч. 1 ст. 43 Цивільного 
процесуального кодексу (далі - ЦПК) України), наприклад: про відвід судді (суду); про відкладення розгляду справи для ознайомлення з матеріалами справи; про відкладення справи із причин хвороби, відрядження, народження дитини тощо; про призначення експертизи; про залучення та допит свідків; про витребування доказів; 2) оскарження судових рішень (п. 5 ч. 1 ст. 43 ЦПК України), наприклад: ухвала суду першої інстанції окремо від рішення суду, зокрема й ухвал, які не передбачені у ст. 353 ЦПК України; 3) подання зустрічного позову відповідачем (п. 3 ч. 2 ст. 49 ЦПК України); 4) подання заяви про врегулювання спору за участю судді (п. 2 ч. 2 ст. 197, ч. 1 ст. 201 ЦПК України); 5) подання клопотань про об'єднання/ роз'єднання позовних вимог (ст. 188 ЦПК України); 6) подання клопотань про залучення співвідповідача (ст. 51 ЦПК України) та/або третіх осіб (ст. ст. 52, 53 ЦПк України) тощо.

Отже, використання вказаних загальних та спеціальних процесуальних прав учасниками цивільного процесу з метою його затягування може бути визнано судом зловживанням процесуальними правами. Серед дій, що суперечать завданню цивільного судочинства, метою яких $\epsilon$ затягування цивільного процесу законодавство виділяє:

- подання скарги на судове рішення, яке не підлягає оскарженню, не $є$ чинним або дія якого закінчилася (вичерпана), подання клопотання (заяви) для вирішення питання, яке вже вирішено судом, за відсутності інших підстав або нових обставин, заявлення завідомо безпідставного відводу або вчинення інших аналогічних дій, що спрямовані на безпідставне затягування чи перешкоджання розгляду справи чи виконанню судового рішення (п. 1 ч. 2 ст. 44 ЦПК України);

- необґрунтоване або штучне об'єднання позовних вимог із метою зміни підсудності справи або завідомо безпідставне залучення особи як відповідача/співвідповідача (п. 4 ч. 2 ст. 44 ЦПК України).

Тобто вагоме значення серед зловживань процесуальним правом мають недобросовісні дії учасників процесу, спрямовані на затягування судового розгляду шляхом маніпулювання встановленими законом строками вчинення певних процесуальних дій [2, с. 165].

3 огляду на норми ЦПК України й усталену судову практику затягування цивільного процесу здебільшого розглядається саме в контексті зловживання процесуальними правами. Однак, виходячи з деяких особливостей, варто розрізняти ці два поняття.

Отже, виділяють такі загальні ознаки зловживання цивільними процесуальними правами, як: недобросовісна реалізація прав особами, які беруть участь у справі; така реалізація суперечить завданням цивільного судочинства; зловживання процесуальними правами спрямоване на порушення як публічних, так і приватних інтересів; воно може здійснюватися у вигляді дій або бездіяльності, як умисно, так і з необережності [3, с. 15].

Ознаками зловживання процесуальними правами в юридичній літературі також називають такі: належне особі суб'єктивне процесуальне право, що здійснюється всупереч його призначенню; відсутня реальна основа здійснюваних дій, яким властива певна штучність; відтворювані особою обставини, що ведуть до невиправданого і штучного ускладнення цивільного процесу і перешкоджають провадженню у справі, а тому зловживання процесуальними правами $\epsilon$ неекономічною процесуальною поведінкою; неприродність, яка виявляється, наприклад, у займанні непослідовної та суперечливої позиції у справі, що з урахуванням інших обставин може зумовити висновок суду про допущене особою зловживання [4, c. 11].

До ознак затягування цивільного процесу, які дозволяють відрізнити його від інших суміжних понять, на думку Г.I. Марунич, належать: 1) негативний вплив на динаміку цивільного процесу у вигляді невиправданого зволікання; 2) сутністю затягування цивільного процесу $\epsilon$ здійснення дій, які не $є$ необхідними для ухвалення законного й обґрунтованого рішення у справі, або нездійснення дій, які $є$ необхідними для ухвалення такого рішення, тобто бездіяльність; 3) коло суб'єктів затягування цивільного процесу становлять ті суб'єкти цивільних процесуальних правовідносин, дії яких впливають на дина- 
міку цивільного процесу; 4) затягування цивільного процесу може здійснюватись як умисно, так і з необережності; 5) затягування цивільного процесу може здійснюватися з моменту звернення особи із заявою до суду до ухвалення судом рішення, яким закінчується розгляд справи. Отже, під затягуванням цивільного процесу варто розуміти діяння суду або учасників судового процесу, які призводять до невиправданого зволікання у вчиненні окремої процесуальної дії і, як наслідок, до відтермінування ухвалення судом рішення, яким закінчується розгляд справи [5, с. 77-78].

Отже, можна виділити взаємопов'язані відмінності між зловживанням цивільними процесуальними правами та затягуванням цивільного процесу: по-перше, зловживанням процесуальними правами, виходячи зі змісту ст. 44 ЦПК України, визнаються дії, що суперечать завданню цивільного судочинства, а затягування цивільного процесу - це не тільки вчинення певних дій, а й бездіяльність (зволікання); по-друге, зловживання процесуальними правами здійснюється учасниками судового процесу, а затягування цивільного процесу може здійснюватись й іншими суб'єктами, наприклад судом або органами державної влади, які несвоєчасно надавали запитувану інформацію тощо; по-третє, зловживання цивільними процесуальними правами може здійснюватись як умисно, так і з необережності, тоді як затягування цивільного процесу відбувається завжди свідомо, з умислом та з метою відтермінування ухвалення судового рішення. Варто також враховувати, що зловживання може бути як процесуальними правами, так і матеріальними. Касаційний цивільний суд у складі Верховного Суду звернув увагу на необхідність розмежовувати вказані вище зловживання, зазначив, що вони відрізняються як по суті, так і за правовими наслідками щодо застосування їх судом. У разі зловживання процесуальними правами суд має право залишити без розгляду або повернути скаргу, заяву, клопотання, позов, застосувати інші заходи процесуального примусу. Натомість правовим наслідком зловживання матеріальними (цивільними) правами може бути, зокрема, відмова в захисті цивільного права й інтересу, тобто відмова в позові
[6]. Затягування ж можливе лише в цивільному процесі, тобто вже після виникнення цивільних процесуальних правовідносин.

3 огляду на викладене, можна вважати, що обов'язок суду забезпечувати своєчасний розгляд цивільної справи забезпечується двома шляхами: своєчасним і добросовісним виконанням власних повноважень і контролем за належним виконанням учасниками цивільного процесу їхніх процесуальних обов'язків, а також не зловживанням цивільними процесуальними правами особами, які беруть участь у справі. 3 огляду на те, що розгляд цивільної справи неможливий без участі суду, а його дії або бездіяльність прямо впливають на розумний строк розгляду справи, суд $\epsilon$ суб'єктом затягування цивільного процесу [3, с. 15].

Окрім так званих законних способів затягування цивільного процесу, існують й такі способи, що стосуються невиконання обов'язків учасниками судового процесу, закріплених у ч. 2 ст. 43, ч. ч. 1, 2 ст. 64, ч. ч. 2, 3 ст. 69, ч. ч. 3, 4 ст. 72, ч. 3 ст. 74, ч. 3 ст. 75 ЦПК України, наслідком чого $€$ застосування заходів процесуального примусу. Отже, учасники справи зобов'язані: виявляти повагу до суду та до інших учасників судового процесу; сприяти своєчасному, усебічному, повному й об'єктивному встановленню всіх обставин справи; з'являтися в судове засідання за викликом суду, якщо їхня явка визнана судом обов'язковою; подавати всі наявні в них докази в порядку та строки, встановлені законом або судом, не приховувати докази; виконувати процесуальні дії у встановлені законом або судом строки; представник, який уповноважений на ведення справи, здійснює обов'язки від імені особи, яку представляє; інші учасники судового процесу мають здійснювати такі обов'язки: свідок зобов'язаний з'явитися до суду у визначений час за викликом і дати правдиві показання про відомі йому обставини; експерт зобов'язаний з'явитися до суду за його викликом та роз'яснити свій висновок і відповісти на питання суду й учасників; спеціаліст зобов'язаний з'явитися до суду за його викликом, відповідати на поставлені судом питання, надавати консультації та роз'яснення, у разі потреби надавати 
суду іншу технічну допомогу; перекладач зобов'язаний з'являтися до суду за його викликом, здійснювати повний і правильний переклад тощо.

Висновки 3 дослідження та перспективи подальших розвідоку цьому

напрямі. Затягування цивільного процесу $є$ одним із видів зловживання процесуальними правами, однак необхідно розмежовувати ці дві категорії, виходячи із суб'єктивних та об'єктивних характеристик.

По своїй суті «затягування» як розглядуваний феномен реалізації цивільних процесуальних прав та обов'язків так чи інакше не тільки стосується, але й охоплюється проблемами прояву аномалій у цивільному процесі, а предмет затягування $\epsilon$ елементом безпекового феномену в цивільному процесі, адже $є$ його об'єктом [6, с. 244]. Феномен аномалій цивільного процесу Я.Я. Мельник пропонує виділяти в окремий комплексний процесуальний інститут цивільного процесу, який повинен знайти місце в доктрині цивільного процесуального права. До суміжних феноменів аномалій в цивільному процесі - віднести інститут прогалин та колізій цивільного процесуального законодавства до похідних - зловживання правом та затягування процесу [7, с. 10].

Після встановлення суб'єктного складу, ознак та способів затягування цивільного процесу варто встановити шляхи подолання таких недоліків цивільного судочинства.

Отже, можна навести такі способи протидії затягуванню цивільного процесу суб'єктами цивільних процесуальних правовідносин та іншими особами.

Припинення затягування цивільного процесу:

1) заходи процесуального примусу застосовуються судом до учасників судового процесу, зокрема в разі визнання їхніх дій зловживанням процесуальними правами з метою затягування цивільного процесу:

- штраф. Суд може з учасника справи стягнути в дохід державного бюджету штраф у сумі від 0,3 до трьох розмірів прожиткового мінімуму для працездатних осіб у випадках: 1) невиконання процесуальних обов'язків, зокрема ухилення від учинення дій, покладених судом на учасника судового процесу; 2) зловживання процесуальними правами, учинення дій або допущення бездіяльності 3 метою перешкоджання судочинству; 3) неповідомлення суду про неможливість подати докази, витребувані судом, або неподання таких доказів без поважних причин; 4) невиконання ухвали про забезпечення позову або доказів, ненадання копії відзиву на позов, апеляційну чи касаційну скаргу, відповіді на відзив, заперечення іншому учаснику справи у встановлений судом строк.

Суд може також стягнути у дохід державного бюджету з відповідного учасника судового процесу або відповідної іншої особи штраф у сумі від одного до десяти розмірів прожиткового мінімуму для працездатних осіб у разі повторного, систематичного чи неодноразового невиконання процесуальних обов'язків, зловживання процесуальними правами, неподання витребуваних судом доказів без поважних причин або без їх повідомлення, триваючого невиконання ухвали про забезпечення позову або доказів.

Суд може стягнути штраф також із представника у випадку невиконання процесуальних обов'язків і зловживання процесуальними правами;

- тимчасове вилучення доказів для дослідження судом. Такій захід процесуального примусу дуже часто застосовується судом у випадках невиконання стороною у справі ухвали про витребування доказів, тобто неподання письмових, речових чи електронних доказів без поважних причин або без повідомлення причин їх неподання. Ухвала про тимчасове вилучення доказів державним виконавцем для дослідження судом $€$ виконавчим документом та підлягає негайному виконанню (ст. 146 ЦПК України);

- попередження і видалення із залу судового засідання. На практиці трапляються випадки коли сторона у справі некоректно себе поводить, іноді навіть запрошує сторонніх осіб, саме з метою «зірвати» судове засідання. Отже, якщо учасники судового процесу, проявляють неповагу до суду та/або до присутніх у судовому засіданні, чим порушують порядок або не виконують розпорядження головуючого, - суд засто- 
совує попередження, а в разі повторного вчинення зазначених дій - видалення із зали судового засідання (ч. 1 ст. 145 ЦПК України);

- привід свідка. Свідок, який є учасником судового процесу, також може сприяти затягуванню цивільного процесу, якщо не з'являється без поважних причин та не повідомляє про причини неявки. У такому разі суд застосовує привід через відповідні органи Національної поліції України з відшкодуванням у дохід держави витрат на його здійснення (ст. 147 ЦПК України);

2) окрема ухвала. Такий спосіб запобігання затягуванню цивільного процесу застосовується судом до різних суб'єктів цивільних процесуальних правовідносин, а також щодо інших осіб, які не $\epsilon$ учасниками судового процесу. Окрему ухвалу може бути постановлено судом першої інстанції, судами апеляційної чи касаційної інстанції, а також Великою Палатою Верховного Суду. Надсилається вона відповідним юридичним та фізичним особам, державним та іншим органам, посадовим особам, які за своїми повноваженнями повинні усунути виявлені судом недоліки або порушення чи запобігти їх повторенню; органу, до повноважень якого належить притягнення до дисциплінарної відповідальності прокурора або адвоката; прокурору чи органу досудового розслідування стосовно свідка, експерта, перекладача в разі виявлення неправдивих показань, висновку та неправильного перекладу, а також стосовно порушення законодавства, що містить ознаки кримінального правопорушення (ст. 262 ЦПК України).

Суд постановляє окрему ухвалу в таких випадках: 1) зловживання процесуальними правами учасниками справи; 2) порушення процесуальних обов'язків учасниками судового процесу, неналежне виконання професійних обов'язків (зокрема, якщо підписана адвокатом чи прокурором позовна заява містить суттєві недоліки або в разі іншого порушення ними законодавства); 3) якщо суд дійде висновку про наявність у діях (бездіяльності) ознак кримінального правопорушення щодо державного виконавця, іншої посадової особи органу державної виконавчої служби, приватного виконавця;
4) виявлення під час розгляду справи відповідно неправдивих показань, неправдивого висновку експерта чи неправильного перекладу, підробки доказів; 5) порушення законодавства або при виявлені недоліків у діяльності юридичної особи, державних чи інших органів та інших осіб; 6) допущення судом нижчої інстанції порушення норм матеріального або процесуального права, незалежно від того, чи $€$ такі порушення підставою для скасування або зміни судового рішення;

3) витрати на розгляд справи:

- забезпечення судових витрат - відповідач має право на забезпечення відшкодування можливих витрат у разі виявлення ознак завідомо безпідставного позову або в разі відмови від позову позивачу, який не має зареєстрованого місця проживання/перебування та майна, тощо (ч. ч. 1, 4, 5 ст. 135 цПК України). Також суд може покласти судові витрати на сторону (повністю/частково) незалежно від результатів вирішення спору у випадку зловживання стороною чи ії представником процесуальними правами, а також якщо спір виник внаслідок неправильних дій сторони (ч. 9 ст. 141 ЦПК України);

- зустрічне забезпечення - суд може забезпечити відшкодування витрат відповідача в разі відмови від позову позивача, який не має зареєстрованого місця проживання/перебування та майна, а також у разі надання доказів, що підтверджують ускладнення або неможливість виконання рішення суду про відшкодування збитків відповідача в разі відмови позивача від позову (ч. ч. 1, 3 ст. 154 ЦПК України);

- відшкодування збитків, завданих забезпеченням позову - відповідач або інша особа, чиї права й інтереси порушені, має право на відшкодування збитків, завданих забезпеченням позову, коштом особи, за заявою якої такі заходи забезпечення позову вживалися (ст. 159 ЦПК України);

- відшкодування витрат, пов'язаних із забезпеченням доказів (ст. 119 ЦПК України);

4) інститут заочного розгляду - застосовується судом у разі нез'явлення без поважних причин у судове засідання відповідача, належним чином повідомленого про дату, час, місце судового засідання 
та який не повідомив про причини своєї неявки і не подав відзив, за умови, що позивач не заперечує проти розгляду справи в порядку заочного розгляду (ст. ст. 223, 280 ЦПК України);

5) апеляційні фільтри - закріплений перелік ухвал, які можуть бути оскаржені окремо від рішення суду та заборона оскарження ухвал суду першої інстанції, яких не має в цьому переліку (ст. 353, ч. 2 ст. 352 ЦПК України);

6) касаційні фільтри - наведений обмежений перелік ухвал суду першої інстанції, які можуть бути оскаржені окремо від рішення суду після їх перегляду в апеляційній інстанції, а також перелік ухвал суду апеляційної інстанції, що оскаржується в касаційному порядку;

7) дисциплінарна відповідальність судді - застосовується щодо судді у випадках: 1) безпідставного затягування або невжиття суддею заходів щодо розгляду заяви, скарги чи справи протягом строку, встановленого законом; 2) зволікання з виготовленням вмотивованого судового рішення; 3) несвоєчасного надання суддею копії судового рішення для ії внесення до Єдиного державного реєстру судових рішень (ст. 106 Закону України «Про судоустрій і статус суддів»).

Запобігання затягуванню цивільного процесу:

1) мирова угода - ухвалюється судом на будь-якій стадії судового процесу за результатами взаємної домовленості сторін із метою врегулювання спору (ст. 207 ЦПК України);

2) урегулювання спору за участю судді - проводиться судом для досягнення сторонами врегулювання спору до початку розгляду справи по суті (ст. ст. 201-205 ЦПК України);

3) розгляд справ у порядку спрощеного позовного провадження - призначений для розгляду малозначних справ, справ незначної складності тощо та здійснюється судом із метою пришвидшення та спрощення розгляду справи (ст. ст. 19, 274-279 ЦПК України);

4) роз'яснення прав і обов'язків учасникам справи - суд має роз'яснити права й обов'язки учасникам судового процесу, а також наслідки їх недотримання або зловживання ними (ст. ст. 218, 220, 221, 225, 226, ч. 3 ст. 230, п. 9 ч. 1 ст. 129 ЦПК України).

\section{ЛITEPATУPA:}

1. Рішення у справі «Дяченко та інші проти України» від 6 липня 2017 р. (заява № 6417/08 та 8 інших заяв у додатку). URL: https://zakon.rada.gov.ua/laws/show/974_b92\#Text

2. Луспеник Д.Д. Зловживання процесуальними правами: законодавча регламентація, способи виявлення та шляхи протидії. Часопис цивільного і кримінального судочинства. № 6 (27). C. 150-171. URL: file://C:/Users/\%D0\%98\%D0\%BD\%D0\%BD\%D0\%B0/Downloads/ Chcks_2015_6_12.pdf

3. Марунич Г.І. «Затягування цивільного процесу» та «зловживання цивільними процесуальними правами»: співвідношення понять. Підприємництво, господарство і право. 2016. № 9. С. 13-18. URL: http://pgp-journal.kiev.ua/archive/2016/09/4.pdf

4. Юдин А.В. Злоупотребление процессуальными правами в гражданском судопроизводстве : автореф. дис. ... докт. юрид. наук: 12.00.15. Санкт-Петербург, 2009. 47 с.

5. Марунич Г.І. Затягування цивільного процесу: сутність, правові наслідки та способи запобігання : дис. ... канд. юрид. наук: 12.00.03. Київ, 2018240 с. URL: http://elar.naiau.kiev. ua/bitstream/123456789/13704/1/dysertatsia_marunych.pdf

6. Постанова Верховного Суду від 3 червня 2020 р. у справі № 318/89/18 (провадження № 61-128св19). URL: https://reyestr.court.gov.ua/Review/89675396

7. Мельник Я.Я. Безпека цивільного процесу: теоретико-правове дослідження : дис. ... докт. юрид. наук. 2019. URL: http://instzak.rada.gov.ua/uploads/documents/31781.pdf 